\section{Final Decision}

Sir,-When I read Professor McCrea's suggestion (Nature, 239, 239; 1972) for limiting scientific publication by a scheme to be called ACRE, I wondered whether he had intended it in satiric vein. $\mathrm{Dr}$ O'Connor's suggestion (Nature, 239, 418; 1972) of calling for support by postcard, before full publication is made, raises a number of serious objections.

Authors in big departments or with a wide circle of friends would doubtless tend to receive more support than others. It would set an extra hurdle in the path of the unorthodox. Authors in fields with few workers might not receive the necessary support in the popularity poll. It would surely accentuate the offering of inferior material to journals with less critical editors.

Over recent years, there has been a tendency, albeit with exceptions, towards shorter papers but it depends greatly on the topic whether argument should be in full and data briefly summarized, or the reverse.
Let us not put ourselves in an unnecessary straitjacket but leave it to editors to assess quality rather than quantity or popularity.

Yours faithfully,

\section{E. A. George}

Culture Centre of Algae and Protozoa, 38 Storey's Way, Cambridge CB3 ODT

\section{DDT and Peregrines}

SIR,--It would have been more enlightening if D. L. Gunn (Nature, 239, 296; 1972) had specified why the evidence I quoted (Nature, 238, 475; 1972), linking the decline of peregrine with the persistent pesticides, was unsound, or had submitted the evidence to the contrary. Instead he says, without quoting the specific references, that "the evidence was examined by the Wilson Committee ${ }^{1}$ and the Mrak Commission ${ }^{2}$ and found to be inadequate".
I commented earlier on his selective use of the Wilson Committee findings and he gives no reasons now for regarding as "not altogether convincing" their suggestion that dieldrin was responsible. The Mrak Commission dealt with the decline of peregrine and other species at some length and concluded (p. 212), "These experiments appear to forge the last link in the chain of evidence that DDT and its derivatives have been the direct and principal cause of widespread and significant reductions in bird populations".

\section{Yours faithfully,}

\section{Stanley Cramp}

32 Queen Court,

\section{London $W C 1 N 3 B B$}

1 Advistory Committee on Pesticides and other Toxic Chemicals, 148 (HMSO, 1969).

2 Report of the Secretary's Commission on Pesticides and their Relationship to Environmental Health, 677 (US Department of Health, Education and Welfare, 1969).

\title{
Obituary
}

\section{Professor Trevor Ian Shaw}

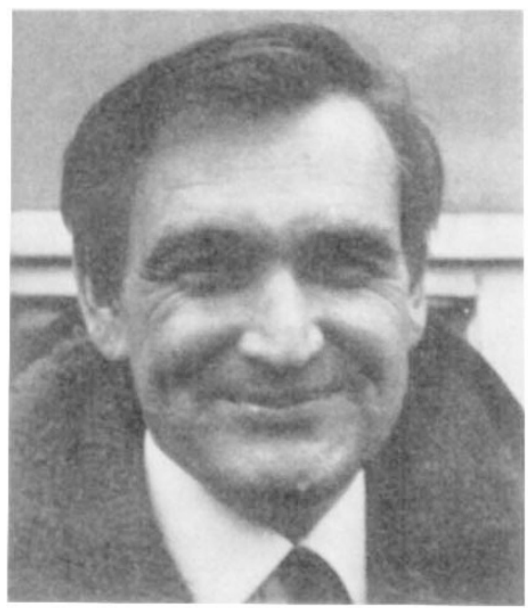

Trevor Shaw was born in 1928 and educated at Bootham School, York, and at Clare College, Cambridge, where he read the Natural Sciences Tripos and where he also studied parts one and two of the Bachelor of Medicine degree. After graduation in 1950 he remained at Cambridge on an MRC studentship to undertake research at the Physiological L.aboratory under the supervision of Sir Alan Hodgkin, PRS. On completing the work for his doctorate in 1953 he was called up for National Service and seconded to the Medical Division of the Chemical Defence Experimental Estab- lishment at Porton until his release from the army in 1955. For the next 11 years he worked at the Plymouth Laboratory of the Marine Biological Association of the United Kingdom, at first on a grant from the Atomic Energy Authority to study the uptake of fission products by marine organisms and then, from 1958 onwards, as a physiologist on the MBA staff. These years at Plymouth were both happy and productive and were marked by a succession of original discoveries which reflected his ability to deal with a number of fundamental problems in biology. In 1966 he was appointed Professor of Zoology in London University and spent the next six years at Queen Mary College. His warm and unassuming character, immense knowledge and infectious enthusiasm won him an ever widening group of appreciative undergraduates and colleagues. He was fully involved in his work up until his premature death on September 26, 1971.

Research work was a central part of Trevor Shaw's life and he was among the first to demonstrate, on red blood cells, a coupling between the transport of sodium and potassium ions. Later he elucidated the mechanism by which seaweeds accumulate iodine but above all he will be remembered for his sustained researches on the properties of nerve membranes. He was a brilliant experimentalist and devised, with $\mathrm{Dr}$ P. F. Baker, a remarkable method of perfusing the giant axon of the squid with artificial media. This allowed the complete control of the contents of an active nerve fibre, a facility which Shaw and Baker together with Sir Alan Hodgkin and other collaborators have brilliantly exploited during recent years.

This distinguished work on ion movements and energetics was only one of Trevor Shaw's many research activities. $\mathrm{He}$ was the first to show, with Dr F. Crescitelli, that the photosensitive visual pigments are circularly dichroic and that this dichroism disappears on bleaching the pigments. He also did very original work on the buoyancy of squid and gelatinous animals such as jellyfish and ctenophores. In the early months of this year he embarked on a new and promising line of research in which he exploited the peculiar properties of laser light to allow the detection of movements of subcellular particles in living nerve cells.

Throughout his research career Trevor Shaw collaborated with some of the most famous physiologists in the country. It was easy to see how these collaborations developed, for he had an insatiable interest in research and a tremendously cooperative approach throughout his whole life. He was a gifted theoretician and never happier than when calculating the exact implications of a ncw idea. It was typical of his intellectual energy that he should spend hours with an insurance agent 
who called to sell him a policy, revising the man's method of calculating premiums and his gentle humour was such that he would later realize the comedy of the situation and delight in relating such tales. The unselfish help which he gave to his colleagues made him a most popular and valuable member of the scientific community. He served on the Councils of the Society for Experimental Biology, the Marine Biological Association and the Freshwater Biological Association and was a committee member of the Physiological Society, the British National Committee for Biology and the British National Committee for Biophysics.
Trevor Shaw's death will be a serious loss to the University of London. Within the period of his tenure of the Chair of Zoology at Queen Mary College he had built up a strong group of experimentalists among his associates and had working ties with engineers, physicists, mathematicians and chemists. He was a scientific polyglot able to converse freely with a wide range of colleagues and he made a unique contribution to the development and teaching of both undergraduate and postgraduate science at the college.

Throughout his life he was in great demand as a lecturer. He visited Leiden, Hamburg, Rome, Illinois, Alabama, the
Max Planck Institute, the College of Physicians and Surgeons at Columbia University and spent extended study periods at UCLA and Duke University, USA, and at Montemar in Chile. Early this year he represented the Royal Society in discussions in Japan with the Japan Academy. He was a Scientific Medallist of the Zoological Society and was elected FRS in 1971.

The distinction and dedication shown in Trevor Shaw's contribution to science will be missed by many. Those who were also fortunate to know him will greatly miss a dear friend who had the warm and generous nature of a most unselfish man.

\section{Errata}

THE following corrections should be made to the article "Selective Feeding of Anopheles gambiae according to ABO Blood Group Status" by Corinne Shear Wood, G, A. Harrison, Caroline Doré and J. S. Weiner (Nature, 239, 165; 1972). The equation at the top of column 2, page 165 , should read:

$$
\text { s.n.d. }=\frac{\log _{\mathrm{e}}\left[\left(r_{\mathrm{o}}+\frac{1}{2}\right) /\left(r_{\mathbf{A}}+\frac{1}{2}\right)\right]}{\left[\left(r_{\mathbf{A}}+\frac{1}{2}\right)^{-1}+\left(r_{0}+\frac{1}{2}\right)^{-1}\right]^{\frac{1}{2}}}
$$

The sentence which starts on line 12 beneath this equation should read "On the null hypothesis that mosquitoes feed randomly with respect to $\mathrm{ABO}$ status, the s.n.d.s have a mean of 0 and the standard deviation of the mean equals $1 / n^{\frac{1}{2}}$."

IN the News and Views note "Successful AID" (Nature, 238, 430; 1972) the period of gestation of artificially inseminated reindeer was incorrectly given as 126 days; the correct figure is 216 days.

IN the article "Oceanic Fine Structure" by H. Charnock (Nature, 239, 32; 1972), the illustration labelled Fig. 1a should be Fig. $1 b$ and vice versa.

THE following corrections should be made to the article "How Bees Navigate" by Allan W. Snyder and Colin Pask (Nature, 239, 48; 1972): the footnote reference numbers at the end of paragraph 1 should be replaced by reference 6 ; footnote reference 7 should be inserted at the end of paragraph 4 and at the end of the legend to Fig. 3; footnote reference 7 in the legend to Fig. 5 should be replaced by reference 9; the first full paragraph on page 50 should read: "It is relevant that bees respond most strongly to blue-ultraviolet electromagnetic waves $1,15,16$, which are not only the most important frequencies in polarized sky light ${ }^{10}$, but are also those which produce the most pronounced electromagnetic mode rejection effect The structure of the drone bee eye ${ }^{13}$ is different from that of the worker.
Furthermore, the drone also has a low resistance between retinular cells ${ }^{14}$ (unlike the worker). These differences may reduce the mode detection. Because the drone rarely leaves the hive, there is no reason for it to have evolved special navigational aids."; footnote reference 16 at the end of the penultimate paragraph should be replaced by 17 ; reference 6 should read Snyder, A. W., and Pask, C., J. Comp. Physiol., 78, 346 (1972); reference 7 should read Snyder, A. W., and Pask, C., J. Opt. Soc. Amer., 12, 1389 (1972); reference 16 should be changed to reference 17 , and a new reference 16 inserted as follows: Gribakin, F. G., Vision Res., 12, 1225 (1972).

\section{Reports and Publicutions}

not included in the Monthly Books Supplement Great Britain and Ireland

National Foundation for Educational Research in England and Wales. The Gifted Child: a Sclect Annotated Bibliography. Compiled by Ann Start. Pp. 40. Admission to Higher Education: a Select Annotated Bibliography. Compiled by Bruce Choppin and Patricia Fara. Pp. 38. Philosophy and Bducationa Research. By John Wilson. Pp. 133. £2.10. (Windsor, Berks: NFER Book Division, Thames Avenue, 【259

Frce Fall To
Dissent No. 2.) Pp. By Francis Pigott. (Essays of Dissent No. 2.) Pp. iti +23 . (Boston, Lincs: Richard
Kay Publications, 1972.) VDI Richtinien: Engine

Dngineering Guidelines Issued by the Association of German Engineers-English Language Index. Pp. 83. (London: Overseas Technical Information Unit, Department of Trade and
Industry, 1972.) $50 \mathrm{p}$.
Welsh Office. Management Arrangements for 450 Reorganized National Health Service in Wales. Pp. iv +95. (Cardiff: HMSO, 1972.) 68p net. $[269$ Department of Education and Science, Welsh Office: Scottish Education Department; Northern Ireland Ministry of Education; University Grants Committec. Education Statistics for the United Kingdom 1970. Pp. xxviii +78. (London: HMSO, 1972. 1.75 net.
[269 Communications of the Dublin Institute for Advanced Studies, Series C. Dunsink Observatory Publi-
cations, Vol. 1, No. 6: Photometric Standards in he Magellanic Clouds. By C. J. Butler. Pp. 133192. Dublin: Dublin Institute for Advanced Studies,

Farm Mechanization Studies No. 24: The Utilization and Performance of Potato Harvesters. Pp. 36 London: Potato Marketing Board, 1972.) Electricity
Electricity $73 / 72-$ Short Version of the Elen Electricity $73 / 72$ - Short Version of the Electricity
Council Annual Report for 1973/1972. Pp. 32 Council Annual Report for 1973/1972. Pp. 32.
(London: The Electricity Counoil, 1972.) Science Research Council/Social Science Research Council. Report on Broader Education for Graduates by the Joint SRC/SSRC Committec. ates by the Joint SRC/SSRC Committec. Pp. v+14. High Holborn, 1972.) Gratis.

Science Research Council. Report of the Council or the year 1971-72. Pp. v+106+6 plates. (London HMSO, 1972.) 73p net.

Imperial College of Science and Technoiogy. Calendar 1972-73. Pp. xi+641. (London: Imperial College, 1972.)
Tropical Products Institute. Methods of Aflatoxin Analysis. By B. D. Jones. Pp. v+46. (London: Commission on Industrial Relations. Report No. 31: Disclosure of Information. Pp. iv +58 . (London: HMSO, 1972.) 45p net. National Coal Board. Report and Accounts 1971 72. Vol. 1: Report. Pp. vii
Accounts and net. (London: HMSO, 1972.) British Nutrition Foundation Limited. Annual Report 1971-1972. Pp. 22. (London: British Nutrition Foundation Limited, 1972.) [299 969-1971 Po. 192 12 plates. (London: The British Muscum (Natural History), 1972,) £1 net. [210 Republic of Ireland. National Science Council. Science Policy Formulation and Resource AllocationReport to the Minister of Finance. Pp. 25. (Dublin: Stationery Office, 1972. For sale by Government Publications Sale Office, G.P.O. Arcade.) 10p. [210 Department of Education and Science. Education Survey No. 16: “Open-Plan"” Primary Schools. Pp.
20. (London: HMSO, 1972.) 21p net. Department of Education and Science. Educational Department of Education and Science. Educational
Priority. Vol. 1: E.P.A. Problems and Policies.
Edited by A. H. Halsey. (Report of a Rescarch Project sponsored by the Department of Education and Science and the Social Science Research Council.) Pp. $\mathrm{xi}+209$. (London: HMSO, 1972.)
net.
[210 Fabian Tract 414: Towards a Radical Agenda:
Commenis on Labour's Programme. Pp. 60. (LonComments on Labour's Programme. Pp. 60. (LonPhilosophical Transactions of the Royal Society of London. A: Mathematical and Physical Sciences. Vol. 273, No. 1232: Non-Symmetric Flow in Laval Type Nozzles. By A. G. Walters. Pp. 185-235. ti.60; $\$ 4.50$. B: Biological Sciences. Vol. 264 No. 863: The Genetics of Mimetic Colour Polymorphism in the Large Narcissus Bulb Fly, Merodon equestris Fab. (Diptera: Syrphidae). By D. L. T.
Conn. Pp 353-402+ plate 39. £1.55; $\$ 4.35$. (LonConn. Pp 353-402+ plate 39. $21.55 ;$ \$4.35. (Lon-
[310 Department of Health and Social Security; Welsh Office. Progress in Salmon. (A report by the Department of Health and Social Security and the Welsh Office.) Pp. 59. (London: Department of Heaith and
[310 Medicine and Society: The Changing Demands for Medical Care. Pp. 32. (London: Office of Health Economics, 1972.) 25p. (London: Otrice of Health Natural Environment Research Council. Report of 1972. Pp. vii $+170+14$ photographs. (London HMSO, 1972.) $£ 1.20$ net. [410 Ion Exchange and Membranes: Science and Technology of Dynamic Macromolecules, Vol. 1, No. 1 August 1972. Edited by J. A. Mikes. Pp. 1-72 Subscription Rates (per volume postpaid, 4 issues per volume): Libraries: USA/elsewhere $\$ 45 / £ 18.75$ Great Britain $£ 17.25$. Individuals (who warrant the journal is for their own use and order direct from the publishers): USA/elsewhere $\$ 16 / £ 6.65$; Great
Britain $£ 5.15$. (London. New York and Paris: Britain t5.15. (London, New York and Paris: Cotton Research Corporation. Progress Reports Pp. 20. Tanzania. Pp. 64. Cotton Research RePp. 20. Tanzania. Pp. 64. Cotton Research Re1970/1971. Pp. 57. (London: Cotton Research Corporation, 1972.) 30p per report. The National Central Library. 56th Annual Report of the Executive Committee for the year ending
31 March. 1972. (London: The National Central 31 March, 1972. (London: The National Central
$[510$

\section{Other Countries}

Canada: Department of the Environment. Marine Scicnces Branch. Marine Science Paper No. 5: Surficial Geology of Northumberland Strait. By Kate Kranck. Pp. iiit 10. (Ottawa: Information Canada,
[229. Symposium Papers on the Role of Nuclear Energy in Australia's Development. June 1st and 2nd. 1972. 